\title{
Some physical and mechanical properties of maritime pine and poplar exposed to oil-heat treatment
}

\author{
Mehmet Taşdelen $^{a}$ (D), Ahmet Can ${ }^{a}$ (D), Hüseyin Sivrikaya ${ }^{a} *$ (iD)
}

\begin{abstract}
Oil-heat treatment is an environmentally friendly method to improve dimensional stabilization of wood. In this process, vegetable oil is used as a heating medium in different temperatures and times. In this study, maritime pine (Pinus pinaster marittima) and poplar (Populus euroamericana) samples subjected to oil heat treatment with safflower, linseed and hazelnut oil at $160{ }^{\circ} \mathrm{C}, 180{ }^{\circ} \mathrm{C}$ and $200{ }^{\circ} \mathrm{C}$ for 2,4 and 6 hours respectively. Water soaking was performed to untreated and oilheat treated samples for two weeks. In this period water uptake and tangential swelling of the samples were measured. In addition, compression strength of the samples was determined parallel to the fiber direction. According to the results, oil-heat treatment considerably reduced the water uptake in maritime pine and poplar while the performance of only vacuum heat treatment was similar with control samples. The improvement in tangential swelling was clearly shown in the poplar samples rather than maritime pine. Vacuum-heat treatment and oil-heat treatment increased the compression strength of maritime pine compared to control samples.
\end{abstract}

Keywords: Oil-heat treatment, Vacuum heat treatment, Safflower, Linseed oil, Hazelnut oil

\section{Yağlı ısıl işlem uygulanmış sahil çamı ve kavak örneklerinin bazı fiziksel ve mekanik özellikleri}

\begin{abstract}
Özet: Yağlı 1sıl işlem ahşabın boyut stabilizasyonunu arttırmak için çevre dostu bir yöntemdir. Bu işlemde yağ farklı sıcaklık ve sürelerde 1S1 ortamı olarak kullanılmaktadır. Bu çalışmada; sahil çamı (Pinus pinaster marittima) ve kavak (Populus euroamericana ) odun örnekleri aspir yağı, keten yağı ve findık yağ işleme tabi tutulmuşlardır. Yağsız ve yağlı isıl işleme maruz bırakılmış odun örnekleri için 2 hafta boyunca su alma testi gerçekleştirilmiştir. Bu süreçte örneklerin su alma ve teğetsel genişleme değerleri ölçülmüştür. Ayrıca örneklerin liflere paralel basınç direnci değerleri tespit edilmiştir. Elde edilen sonuçlara göre yağlı ssıl işlem sahil çamı ve kavak örneklerinin su alma oranlarını önemli ölçüde azaltırken, vakum altında 1 sıl işlem uygulanan örnekler kontrol ile benzer davranışlar sergilemiştir. Kavak örneklerinde teğetsel genişleme sahil çamı örneklerine kıyasla gözle görülür oranda iyileşmiştir. vakum-1sıl işlem ve yağlı ısl işlem kontrol örneklerine kıyasla sahil çamının basınç direncini artırmıştır.
\end{abstract}

Anahtar kelimeler: Yağlı ssıl işlem, Vakumlu 1 ssıl işlem, Aspir, Keten yağı, Fındık yağı

\section{Introduction}

Wood modification improves dimensional stabilization of wood, and gains resistance against the biological organisms such as fungi and insect. According to Hill (2006), thermal modification is performed between $180{ }^{\circ} \mathrm{C}$ and $260{ }^{\circ} \mathrm{C}$, while the lower temperatures below $140{ }^{\circ} \mathrm{C}$ bring about slight changes in the properties of wood, higher temperatures cause degradation in the structure of the material. On the other hand, thermal treatment of wood in a hot oil is an another option since the boiling point of the many vegetable oils are higher than the temperatures to be used for the heat treatment of wood. Thus, wood properties can be improved by oil-heat treatment (OHT) due to the behavior of boiling oil in comparison to heat treatment, which take place in the presence of inert gas. Oil-heat treatment plant was commercially developed by Menz-Holz in Germany. In this process, the temperature at $220{ }^{\circ} \mathrm{C}$ was suggested to obtain maximum durability and minimum oil consumption, for maximum durability and maximum strength the temperatures between $180{ }^{\circ} \mathrm{C}$ and $200{ }^{\circ} \mathrm{C}$ are used with a controlled oil uptake, and crude vegetable oil like rape seed, linseed or sunflower oil as heating medium (Rapp and Sailer, 2000).

The research experiments regarding vegetable oils in the modification of wood have increased in the last decade. With the heat treatment of wood, improvements in hygroscopicity and dimensional stability is explained by chemical reactions due to the high temperature. Heat treatment in an oil bath also improves the performance of wood, especially by reducing the water uptake (Wang and Cooper, 2005).

Awoyemi et al. (2009) studied with the ponderosa pine and black spruce in soybean oil at $220{ }^{\circ} \mathrm{C}$ for 2 hours following cooling inside the hot oil at $180{ }^{\circ} \mathrm{C}$ and $135^{\circ} \mathrm{C}$, resulting in the oil uptake increasing with the cooling time. Thereby, higher reductions in water uptake and swelling were obtained with the higher hydrophobicity and

\footnotetext{
$\bowtie \quad$ a Department of Forest Industrial Engineering, Faculty of Forestry, Bartin University, Bartin, Turkey

@ * Corresponding author (İletişim yazarı): hsivrikaya@bartin.edu.tr

$\checkmark \quad$ Received (Geliş tarihi): 16.05.2019, Accepted (Kabul tarihi): 24.09.2019
}

Citation (Atıf): Taşdelen, M., Can, A., Sivrikaya, H., 2019. Some physical and mechanical properties of maritime pine and poplar exposed to oil-heat treatment. Turkish Journal of Forestry, 20(3): 254-260. DOI: $10.18182 /$ tjf.566647 
dimensional stability through oil cooling for both species. Swelling and moisture uptake of poplar were investigated with sunflower, linseed and rapeseed oil by oil heat treatment process. Equilibrium moisture content (EMC) and swelling were reduced by OHT. Duration and temperature were important parameters affecting the degree of swelling, and increasing in these parameters resulted in decreasing in the EMC and increasing in anti-swelling efficiency (ASE) (Bak and Nemeth, 2012a). Treatment of aspen wood in hot linseed oil can improve the EMC and volumetric shrinkage and increase the decay resistance. Higher resistance against white and brown rot fungi was achieved by the higher temperature in the process (Bazyar, 2012).

The objective of this study was to investigate the effect of oil-heat treatment in different temperatures and durations with safflower oil, hazelnut oil and linseed oil as a reference on some physical and mechanical properties of maritime pine and poplar as well as compare the vacuum-heat treatment and oil-heat treatment process.

\section{Material and Methods}

\subsection{Material}

Maritime pine (Pinus pinaster) and poplar (Populus euroamericana) samples were selected as wood species, because they are both fast growing. The timbers were free of defects and discoloration, cut into the small sizes according to the experiments for water uptake and compression strength.

The vegetable oils (safflower, hazelnut and linseed oil) used in the study were obtained from a company ONEVA (Istanbul) where the production is based on special cold press method. Cold press method is used without any thermal or chemical treatment. The vegetable oils mentioned above were used in the hot oil treatment.

\subsection{Methods}

Vacuum-heat treatment: In this process, wood specimens were exposed to selected temperatures at $160{ }^{\circ} \mathrm{C}$, $180{ }^{\circ} \mathrm{C}$ and $200{ }^{\circ} \mathrm{C}$ for 2,4 and 6 hours respectively. The samples placed in to oven when the target temperature was reached, at the same time vacuum process was started (675 $\mathrm{mmHg}-2,4$ and 6 hours).

Oil-heat treatment: Before oil heat treatment, wood samples were oven dried at $103{ }^{\circ} \mathrm{C}$ until the constant weight. Dried wood samples were placed in $250 \mathrm{ml}$ beakers and stone weights were placed on them to prevent floating of the samples. Safflower, hazelnut and linseed oils were poured into glass beakers 1 liter in size for each one and placed in the oven, exposed to heating until to the $160{ }^{\circ} \mathrm{C}, 180^{\circ} \mathrm{C}$ and $200{ }^{\circ} \mathrm{C}$ respectively. The temperature of the oil was monitored with a thermometer during the heating stage. When the temperature of the oil reached to target temperature hot oil poured in to beakers with wood samples left in the oven for 2, 4 and 6 hours. At the end of the treatment time for each oil, the wood samples taken from the hot oil.

Water uptake: Wood samples with the dimensions of 20 x 20 x $10 \mathrm{~mm}$ (RxTxL) were used for water uptake. The dimensions and weights of the test and control samples were measured in the oven dry conditions before water absorption. The samples were soaked in deionized water in the jars. The samples were weighed at 2, 4, 6, 24, 48, 72 hours, 1 and 2 weeks intervals during the water uptake test. Water absorption was calculated based on the weight differences for individual samples according to formula 1.

$$
\mathrm{WA}=\frac{\mathrm{W} 2-\mathrm{W} 1}{\mathrm{~W} 1} \times 100
$$

where

$\mathrm{W}_{2}$ is the weight of the samples after soaking $(\mathrm{g}), \mathrm{W}_{1}$ is the oven dried weight of the samples $(\mathrm{g})$,

Tangential swelling: Tangential swelling was performed on the control and test samples exposed to water uptake. The lengths of the wood samples in the tangent direction were measured by digital calipers at the specified periods. The expansion ratio was calculated from the difference in the tangential direction for each sample before and after water soaking to the following formula 2 .

$$
\mathrm{TG}(\%)=\frac{\mathrm{T} 2-\mathrm{T} 1}{\mathrm{~T} 1} \times 100
$$

$T_{2}$ is the tangential length at any given time during water soaking $(\mathrm{mm})$ and $T_{1}$ is the Tangential length of the ovendried wood (mm).

Compression strength: Wood samples were prepared in the dimensions of $20 \times 20 \times 30 \mathrm{~mm}$ (tangential $\mathrm{x}$ radial $\mathrm{x}$ fiber direction) in accordance with the TS 2472 (2005) standard. Before experiment, wood samples kept in the chamber at $21{ }^{\circ} \mathrm{C}$ and $65 \% \mathrm{RH}$ to the equilibrium moisture content. Compression force was applied on the samples parallel to the fiber direction by Universal test machine. Compression strength is calculated according to the formula 3.

$$
\sigma ß=\frac{F \max }{a x b}
$$

$\sigma ß$ : compression strength parallel to the fiber direction $\left(\mathrm{N} / \mathrm{mm}^{2}\right)$

Fmax: Maximum crushing load $(\mathrm{N})$

$a$ and $b$ : cross section of the sample (mm)

\section{Results and discussion}

In the present study, weight percent gains (WPG) of the wood samples were not given since they did not make sense under different temperature and durations. It might be attributed to the cooling period which was not allowed to the oil-heat treated samples. Earlier authors drew attention to the cooling period which resulted in the increasing of WPG (Awoyemi et al., 2009; Dubey et al., 2012). Another reason might be the selection of the wood samples from the different batches.

\subsection{Water uptake}

Figure 1 showed that the most important finding regarding maritime pine was that the water uptake of the control samples which was much higher than oil-heat treated samples. When examined the only vacuum heat treated samples they gave similar results with the control samples in relation to water uptake. 
At the beginning of the test ( 2 hours), water absorption of the samples heat treated at $200{ }^{\circ} \mathrm{C}$ was lower than those vacuum heat treated at $160{ }^{\circ} \mathrm{C}$ and $180{ }^{\circ} \mathrm{C}$, but this difference was disappeared when the soaking time reached to 336 hours. It is stated that the reducing in hygroscopy of wood is attributed to the mass loss resulting from the degradation of hemicellulose, the most hydrophilic component in the cell wall, during the thermal treatment (Bourgois and Guyonnet, 1988). Metsä-Kortelainen et al. (2006) pointed out a noticeable exception in their study on the water absorption of sapwood and heartwood of Scots pine and Norway spruce heat-treated at $170{ }^{\circ} \mathrm{C}, 190^{\circ} \mathrm{C}$, $210^{\circ} \mathrm{C}$ and $230^{\circ} \mathrm{C}$. In that study, water absorption of Scots pine sapwood was increased by heat treatment at $170{ }^{\circ} \mathrm{C}$, $190{ }^{\circ} \mathrm{C}$ and $210^{\circ} \mathrm{C}$ compared to the reference samples.

Treatment with safflower oil resulted in higher water uptake especially at $200{ }^{\circ} \mathrm{C}$ for 4 and 6 hours. In first two hours, lower absorption was obtained to the samples treated at $180{ }^{\circ} \mathrm{C}$, then ranged from $24 \%$ to $34 \%$. At the temperatures of $160{ }^{\circ} \mathrm{C}$ and $180{ }^{\circ} \mathrm{C}$ water absorption increased in the case of 6 hours treatment with safflower oil. However, the low water uptake at $160{ }^{\circ} \mathrm{C}$ for 2 hours was a surprising finding to maritime pine.

When used linseed oil, the best results regarding water uptake were obtained by the treatments including $180^{\circ} \mathrm{C}$ for $2 \mathrm{~h}(24 \%)$ and $160{ }^{\circ} \mathrm{C}$ for $6 \mathrm{~h}(28 \%)$, whereas the highest water uptake occurred at $200{ }^{\circ} \mathrm{C}$ for $2 \mathrm{~h}(71 \%)$.

Wood samples treated with hazelnut oil had less impact on water uptake when the heating applied at $160{ }^{\circ} \mathrm{C}$ particularly for 2 and $4 \mathrm{~h}$. However, heating at $180{ }^{\circ} \mathrm{C}$ for 2 and $4 \mathrm{~h}$ effectively reduced the water uptake. This was also maintained at $200{ }^{\circ} \mathrm{C}$ for $2 \mathrm{~h}$. However, treatment time over $2 \mathrm{~h}$ increased the hazelnut oil absorption at $200{ }^{\circ} \mathrm{C}$ in maritime pine.
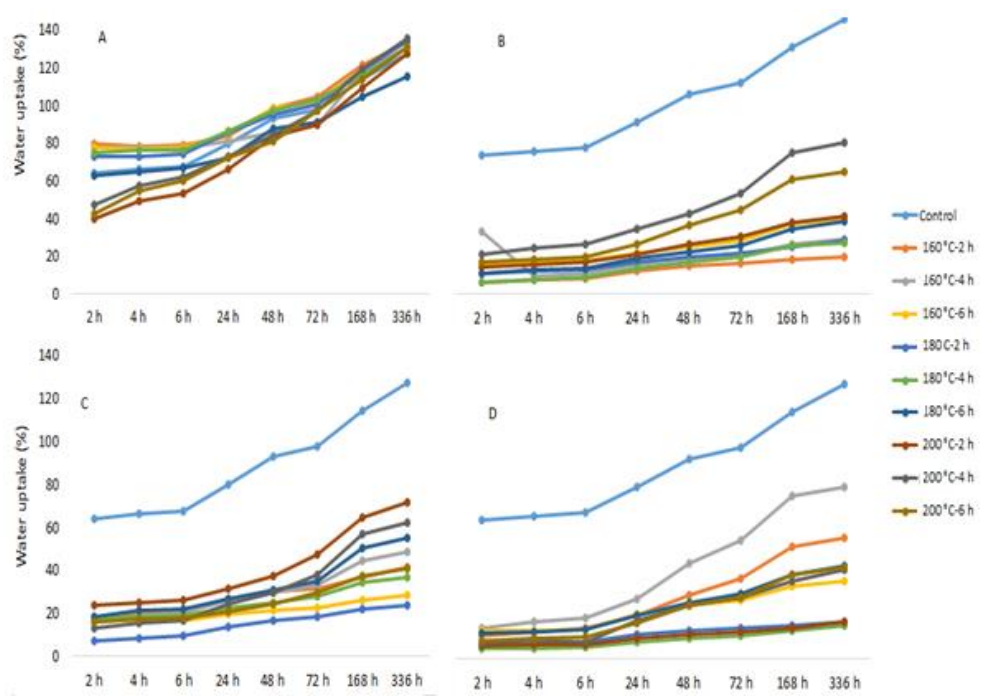

Figure 1. Water uptake of vacuum- heat treated maritime pine (A), heat treated with safflower oil (B), heat treated with linseed oil (C), heat treated with hazelnut oil (D)

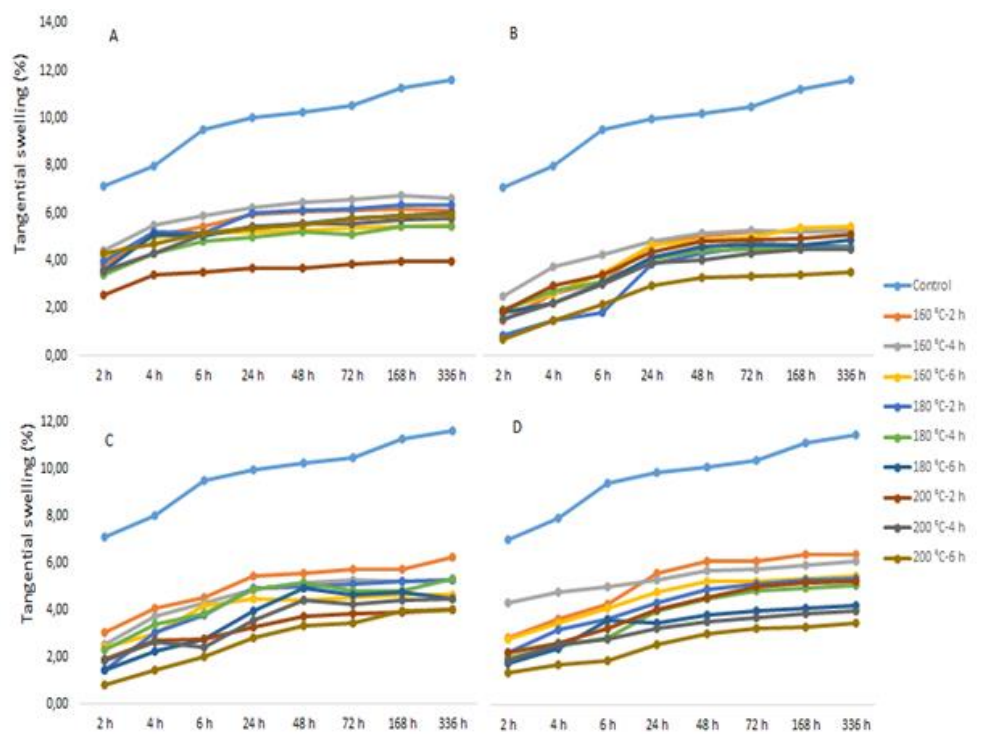

Figure 2. Water uptake of vacuum-heat treated poplar (A), heat-treated with safflower oil (B), heat-treated with linseed oil (C), heat-treated with hazelnut oil (D) 
When examined the results with poplar samples, Figure 2 (B) illustrates that the poplar control samples showed either little bit higher or lower water uptake than heattreated samples to the soaking period ranged from $2 \mathrm{~h}$ to 168 $\mathrm{h}$. However, the difference in water uptake between control and heat-treated samples was more distinct after $168 \mathrm{~h}$ soaking. It is understood from these results that heat treated wood under vacuum is susceptible to water absorption like control samples. As it was in maritime pine, water uptake of the poplar control samples maintained higher trend than oil heat-treated samples for overall durations from 2 hours to 336 hours. However, the difference in water uptake was very low between control and only heat-treated samples, even if it was some higher in the last period, when compared to oil heat treatment.

Treatment with safflower oil resulted in better result at $180{ }^{\circ} \mathrm{C}(34.01 \%)$ and $200{ }^{\circ} \mathrm{C}(40.49 \%)$ for $2 \mathrm{~h}$ respectively, whereas increasing in the duration increased the water uptake at these temperatures in poplar. When used the linseed oil, the water uptake was much lower than those treated with safflower oil. For instance, water uptake was ranged from $26 \%$ to $51 \%$ depending on the temperature and time in the case of linseed oil, whereas it was between $34 \%$ and $97 \%$ with safflower oil. Modification of poplar with hazelnut oil highly improved the water uptake compared to the control samples. The rate of water absorption varied depending on the temperature and duration. The absorption was relatively lower at $180{ }^{\circ} \mathrm{C}$ and $200{ }^{\circ} \mathrm{C}$ for $2 \mathrm{~h}$ than other variations.

Salim et al. (2010) reported that bamboo became less hygroscopic using crude palm oil due to the higher temperature at $220^{\circ} \mathrm{C}$ and $180{ }^{\circ} \mathrm{C}$ in addition to longer heat treatment like $60 \mathrm{~min}$. Bak and Nemeth (2012), conducted studies on poplar wood with similar parameters within the our study including the temperatures at $160^{\circ} \mathrm{C}$ and $200{ }^{\circ} \mathrm{C}$ for 2, 4 and 6 hours, and sunflower, linseed and rapeseed oil as heating medium. They found that there was no significant difference among the vegetable oils with regard to antiswelling efficiency. They obtained the best dimensional stabilization in the radial and tangential direction with the linseed oil. In addition, in the evaluation of EMC results, treatment at $160{ }^{\circ} \mathrm{C}$ for 6 hours was better than treatment at $200{ }^{\circ} \mathrm{C}$ for 2 hours. The moisture content was lower in oil heat-treated wood than untreated wood, and treatment at 200 ${ }^{\circ} \mathrm{C}$ resulted in the best. Bazyar (2012), found lower water absorption $(22.9 \%)$ at the temperature of $200{ }^{\circ} \mathrm{C}$ and the highest water absorption (99.99\%) in the control samples when aspen wood exposed to oil heat treatment with linseed oil.

\subsection{Tangential swelling (TG\%)}

After water uptake test, control samples of maritime pine showed partially similar TG behavior with only heat treated samples, while treatment at $200{ }^{\circ} \mathrm{C}$ for 4 hours improved the tangential swelling by $14.90 \%$ compared to control samples $(5.67 \%)$. Minimum TG values were obtained by heat treatment alone at $160{ }^{\circ} \mathrm{C}, 180{ }^{\circ} \mathrm{C}$ and 200 ${ }^{\circ} \mathrm{C}$ for 4 hours. This was confirmed by figure 3 (A) which indicated that 4 hours heat treatment was more suitable in maritime pine to reduce TG. Kamperidou et al. (2013) examined the water absorption and swelling properties of Scots pine samples which were subjected to thermal treatment at $200{ }^{\circ} \mathrm{C}$, for 4,6 , and $8 \mathrm{~h}$. They found that swelling percentage in the tangential direction decreased by $10.26 \%, 17.22 \%$, and $19.60 \%$ respectively after $72 \mathrm{~h}$ immersion. In addition, absorption percentage decreased by $0.77 \%, 6.52 \%$, and $17.57 \%$ respectively.
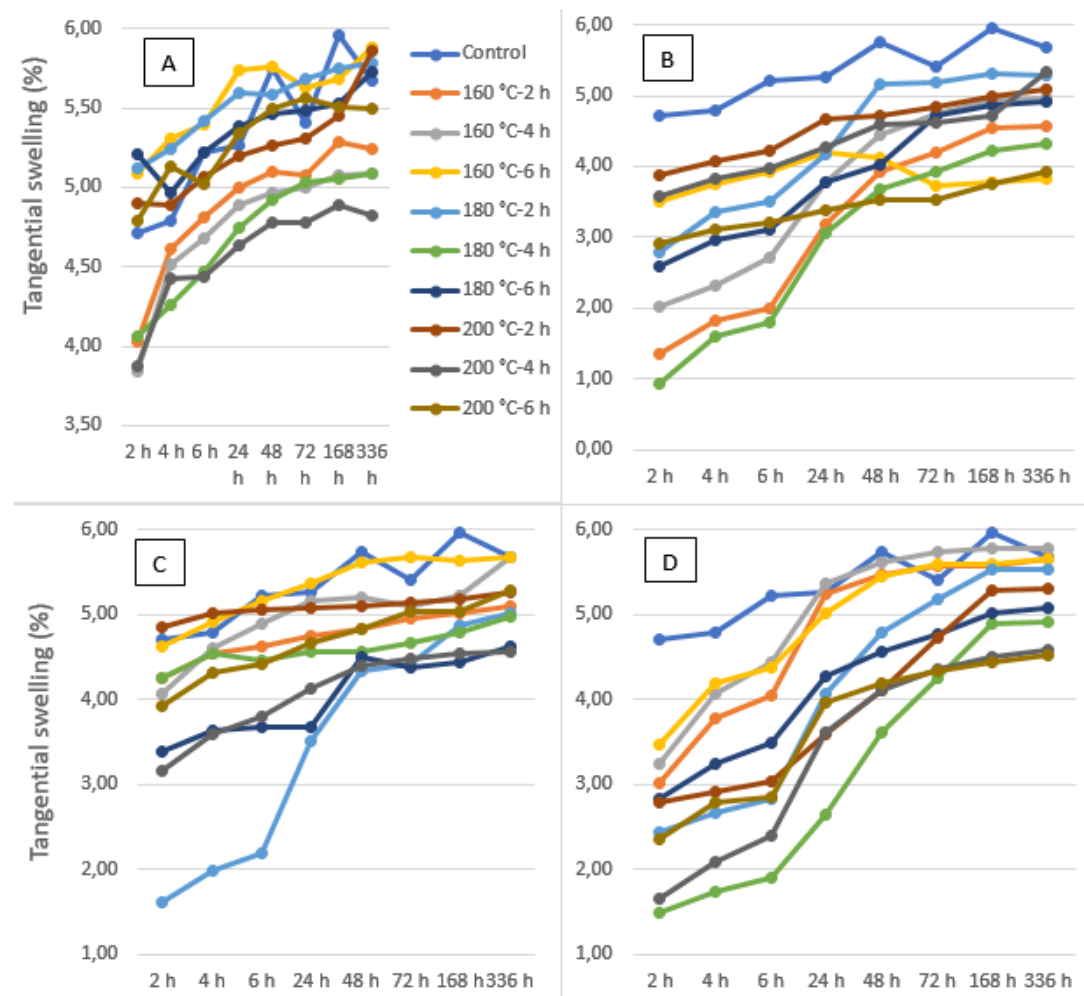

Figure 3. Tangential swelling of vacuum-heat treated maritime pine (A), heat treated with safflower oil (B), heat treated with linseed oil (C), heat treated with hazelnut oil (D) 
In the present study, TG values showed decrease for all temperatures and durations in the case of safflower oil in comparison to the control samples after 2 weeks in maritime pine. The lowest TG values were obtained by heat treatment using safflower oil for 6 hours at $160{ }^{\circ} \mathrm{C}$, with linseed oil for 6 hours at $180{ }^{\circ} \mathrm{C}$, and with hazelnut oil for 6 hours at 200 ${ }^{\circ} \mathrm{C}$. Figures 3 indicated that 6 hours oil heat treatment generally was found to be effective in the improvement of tangential swelling, however, the degree of temperature showed difference according to the oil type used in the study (Fig. 4).

In the poplar control samples, the tangential swelling value was $7.12 \%$ at the beginning ( 2 hours) of soaking but, then reached to $11.63 \%$ after 336 hours. It was also shown that vacuum-heat treatment alone significantly reduced the tangential swelling, moreover the difference in temperature and duration during heat treatment did not considerably effect the tangential swelling except for $200{ }^{\circ} \mathrm{C}$ for 2 hours.

In the heat-treated samples, the lowest TG was obtained with the samples treated with $200{ }^{\circ} \mathrm{C}$ for 2 hours, whereas the highest $\mathrm{TG}$ was obtained by $160{ }^{\circ} \mathrm{C}$ for 4 hours. Tangential swelling was improved by $65 \%$ with heat treatment at $200{ }^{\circ} \mathrm{C}$ for 2 hours compared to the control samples. It can be stated that heat treatment reduces the tangential swelling in wood by providing dimensional stabilization.

Ghalehno (2011) found a reduction by $40 \%$ in tangential swelling value and a reduction by $37.15 \%$ in radial swelling after 9 hours of heat treatment at $190{ }^{\circ} \mathrm{C}$. In a study using poplar, the radial, tangential and volumetric swelling values of the control samples were $4.39 \%, 8.99 \%$ and $12.95 \%$, respectively, while those of heat treated samples were reported to be $2.99 \%, 6.98 \%$ and $9.8 \%$ (Bazyar et al., 2010). The longer time of heat treatment such as 10 hours at 180 ${ }^{\circ} \mathrm{C}$ reduced the tangential swelling by $2,6 \%$ for the samples of wild pear (Pyrus elaeagnifolia) (Gündüz et al., 2009). In another study, it was stated that heat treatment had a positive effect on the physical properties of wood (Ozan et al., 2017).

Reduction in water uptake and improvement of water repellency in wood by vegetables oils were explained by some authors. Vegetable oils reduce the water uptake of wood by creating a mechanical barrier function without any chemical bonding (Panov et al., 2010), and provide water repellency to wood by penetrating in to tracheid lumen and parenchyma cells (Ulvcrona, 2006). Vegetable oil filling the cell lumen is stored on the outer surfaces and partly the inner surfaces, so that the wood surface gains hydrophobicity. Thus, the rate of water uptake is reduced because the water penetrates in to wood through the pores with capillary action (Koski, 2008).

When poplar wood exposed to safflower oil at $200{ }^{\circ} \mathrm{C}$ for 6 hours tangential swelling decreased by $70 \%$ compared to control samples, furthermore decreased by $41 \%$ in comparison to only heat treatment at $200{ }^{\circ} \mathrm{C}$ for $6 \mathrm{~h}$ in the absence of oil. TG was reduced by $65 \%$ and $69 \%$ respectively with linseed and hazelnut oil for 6 hours at 200 ${ }^{\circ} \mathrm{C}$ compared to the control samples.

All vegetable oils used in this study for heat treatment lowered the TG values in poplar samples when compared to control samples. Overall experiments indicated that the most improvement in tangential swelling achieved by the treatment at $200{ }^{\circ} \mathrm{C}$ for 6 hours for three types of vegetable oils.
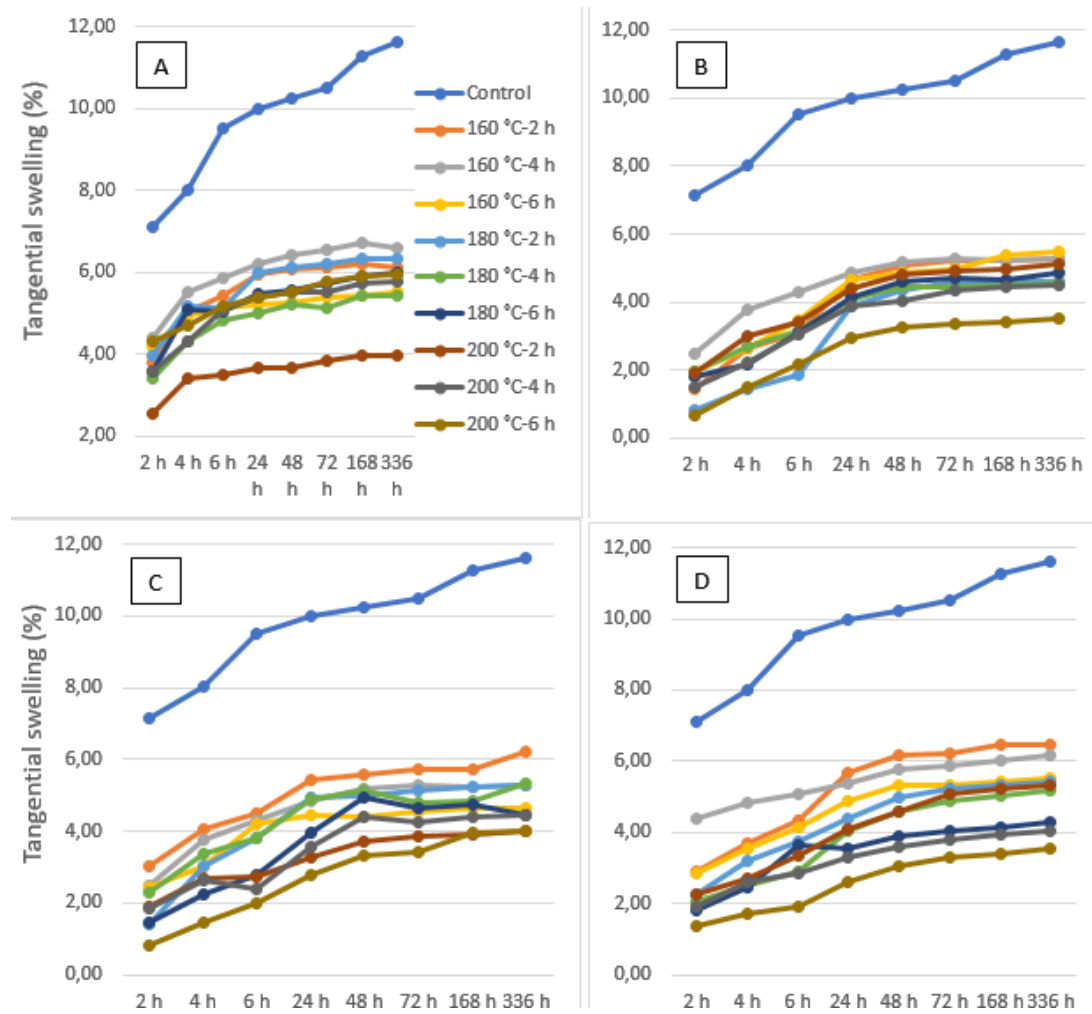

Figure 4. Tangential swelling of vacuum-heat treated poplar (A), heat treated with safflower oil (B), heat treated with linseed oil (C), heat treated with hazelnut oil (D) 


\subsection{Compression strength}

Compression strength of maritime pine was found to be $33 \mathrm{~N} / \mathrm{mm}^{2}$ for control samplesof maritime pine. In comparison to the control samples, all treatments either vacuum-heating or oil heat treatment increased the compression strength in maritime pine (Table 1). To the heat-treated samples, compression strength decreased with the increasing in temperature and duration of the treatment. This means that the higher values of compression strength were obtained by the heat treatment at $160{ }^{\circ} \mathrm{C}$. Unsal and Ayrilmis (2005) investigated the heat treatment of Eucalyptus wood at the temperatures ranged from $120^{\circ}$ to $180^{\circ} \mathrm{C}$ for durations from 2 to $10 \mathrm{~h}$. According to the findings of Eucalyptus samples, compression strength decreased with increasing temperature and times by overall treatments when they heat. In our study, there was no linear relationship between the temperature and duration in the maritime pine samples treated with hot oil. Treatment with safflower oil resulted in higher compression strength except for the treatment at $160{ }^{\circ} \mathrm{C}$ for 2 hours. However, strength values of safflower oil were found to be lower than only heat treated samples except for the treatment at $200{ }^{\circ} \mathrm{C}$ for 6 hours.

Compression strength of maritime pine was significantly reduced by linseed oil when the samples subjected to $200^{\circ} \mathrm{C}$ for 6 hours, but other treatments with linseed oil generally produced high strength values particularly for $180{ }^{\circ} \mathrm{C}$ compared to vacuum heat treatment alone. Treatment with hazelnut oil usually exhibited increasing values with the increasing in temperature and time. In the samples treated with hazelnut oil at $200{ }^{\circ} \mathrm{C}$ for $4-6$ hours resulted in higher values than other experiments with the same oil.

Compression strength of poplar was obtained to be $44,33 \mathrm{~N} / \mathrm{mm}^{2}$ for control samples. Poplar samples gave lower strength values when subjected to only heat treatment than the control samples (Table 2). The difference was not markedly higher for only heat-treated samples between 160 ${ }^{\circ} \mathrm{C}$ and $180{ }^{\circ} \mathrm{C}$ or $180{ }^{\circ} \mathrm{C}$ and $200{ }^{\circ} \mathrm{C}$. When the poplar samples treated with safflower oil, the highest result of compression strength was given by $200{ }^{\circ} \mathrm{C}$ for $6 \mathrm{~h}$, and little differences revealed for other temperatures and time. 4 hours duration at the temperatures $160{ }^{\circ} \mathrm{C}$ and $180{ }^{\circ} \mathrm{C}$ increased the compression strength when used the linseed oil. However, treatment at $200{ }^{\circ} \mathrm{C}$ particularly for $6 \mathrm{~h}$ sharply reduced the compression strength in poplar. Treatment with hazelnut oil had the lowest strength values in the case of 160 ${ }^{\circ} \mathrm{C}$ for $2 \mathrm{~h}\left(12,50 \mathrm{~N} / \mathrm{mm}^{2}\right)$ and $200{ }^{\circ} \mathrm{C}$ with $6 \mathrm{~h}(27,75$ $\mathrm{N} / \mathrm{mm}^{2}$ ), the other temperatures and durations displayed higher compression strength. Bak and Nemeth (2012b), found increasing in compression strength by $15-25 \%$ in the oil-heat treatment of poplar with the increasing time and temperature.

In our study, it was shown that oil-heat treatment showed little increase and decrease in the compression strength of the poplar depending on the oil type, temperature and duration.

Table 1. Compression strength of oil-heat treated maritime pine $\left(\mathrm{N} / \mathrm{mm}^{2}\right)$

\begin{tabular}{|c|c|c|c|c|}
\hline Treatments & Vacuum-heat treatment & Safflower oil & Linseed oil & Hazelnut oil \\
\hline $160^{\circ} \mathrm{C}-2 \mathrm{~h}$ & $69,20(1,48)$ & $34,00(3,46)$ & $56,67(5,51)$ & $57,00(2,00)$ \\
\hline $160^{\circ} \mathrm{C}-4 \mathrm{~h}$ & $66,60(2,61)$ & $47,00(4,36)$ & $62,75(4,43)$ & $62,00(8,66)$ \\
\hline $160^{\circ} \mathrm{C}-6 \mathrm{~h}$ & $65,50(1,91)$ & $57,50(0,71)$ & $67,00(6,00)$ & $52,33(2,52)$ \\
\hline $180^{\circ} \mathrm{C}-2 \mathrm{~h}$ & $60,40(4,51)$ & $61,50(0,71)$ & $69,50(3,00)$ & $47,50(3,54)$ \\
\hline $180^{\circ} \mathrm{C}-4 \mathrm{~h}$ & $59,20(2,86)$ & $52,33(5,51)$ & $67,33(7,02)$ & $56,33(2,08)$ \\
\hline $180^{\circ} \mathrm{C}-6 \mathrm{~h}$ & $57,60(2,61)$ & $51,00(4,32)$ & $69,25(4,79)$ & $60,40(5,27)$ \\
\hline $200^{\circ} \mathrm{C}-2 \mathrm{~h}$ & $56,67(5,51)$ & $50,50(3,70)$ & $60,40(4,98)$ & $55,50(2,89)$ \\
\hline $200^{\circ} \mathrm{C}-4 \mathrm{~h}$ & $50,80(3,56)$ & $48,25(1,89)$ & $52,00(3,46)$ & $64,33(3,06)$ \\
\hline $200^{\circ} \mathrm{C}-6 \mathrm{~h}$ & $47,75(3,69)$ & $61,00(5,29)$ & $35,67(5,03)$ & $64,00(3,46)$ \\
\hline
\end{tabular}

Table 2. Compression strength of oil-heat treated poplar $\left(\mathrm{N} / \mathrm{mm}^{2}\right)$

\begin{tabular}{|c|c|c|c|c|}
\hline Treatments & Vacuum-heat treatment & Safflower oil & Linseed oil & Hazelnut oil \\
\hline $160^{\circ} \mathrm{C}-2 \mathrm{~h}$ & $42,20(2,59)$ & $46,40(3,51)$ & $41,75(3,30)$ & $12,50(0,71)$ \\
\hline $160^{\circ} \mathrm{C}-4 \mathrm{~h}$ & $39,00(4,24)$ & $41,50(1,73)$ & $51,67(1,53)$ & $38,00(3,61)$ \\
\hline $160^{\circ} \mathrm{C}-6 \mathrm{~h}$ & $37,75(2,50)$ & $39,50(4,95)$ & $46,20(2,05)$ & $38,00(4,24)$ \\
\hline $180^{\circ} \mathrm{C}-2 \mathrm{~h}$ & $38,60(1,82)$ & $45,00(3,56)$ & $41,50(3,87)$ & $45,00(1,73)$ \\
\hline $180^{\circ} \mathrm{C}-4 \mathrm{~h}$ & $37,20(1,92)$ & $44,20(4,92)$ & $50,50(3,32)$ & $47,00(5,57)$ \\
\hline $180^{\circ} \mathrm{C}-6 \mathrm{~h}$ & $36,00(2,12)$ & $44,00(0,00)$ & $49,00(0,00)$ & $49,50(4,20)$ \\
\hline $200^{\circ} \mathrm{C}-2 \mathrm{~h}$ & $36,75(1,50)$ & $49,80(3,11)$ & $42,67(4,93)$ & $43,00(1,00)$ \\
\hline $200^{\circ} \mathrm{C}-4 \mathrm{~h}$ & $34,50(1,29)$ & $47,40(2,07)$ & $42,00(1,41)$ & $44,33(4,51)$ \\
\hline $200^{\circ} \mathrm{C}-6 \mathrm{~h}$ & $36,00(2,94)$ & $51,50(2,38)$ & $15,00(2,58)$ & $27,75(3,30)$ \\
\hline
\end{tabular}




\section{Conclusion}

For maritime pine, water uptake of the oil heat treated samples were considerably lower than control and vacuumheat treated samples. Obtaining of the higher water absorption by vacuum-heat treatment alone may be due to the vacuum process which might prevents the degradation of $\mathrm{OH}$ groups present in polysaccharides during heat treatment.

Poplar samples treated with vegetable oils significantly reduced the water uptake in comparison to the control and vacuum-heat treated samples as in the maritime pine samples. In poplar samples, linseed oil reduced the water absorption more than safflower oil.

For poplar samples, generally, all vegetable oils revealed similar behaviour by considerably reducing the tangential swelling compared to control samples. However, in the tangential swelling of maritime pine, the results obtained from control samples were close to those treated with vegetable oils.

To reduce tangential swelling, 6 hours treatment time was found to be effective for vegetable oils, while 4 hours was reasonable for vacuum-heat treatment in maritime pine.

Both vacuum-heat treatment and oil-heat treatment with vegetable oils considerably increased the compression strength in maritime pine.

\section{Acknowledgments}

Authors would like to thanks Bartin University, Scientific Research Coordination Office (Project number: 2016-FEN-C-006) for the financial support

\section{References}

Awoyemi L, P.A., Cooper, Ung T.Y., 2009. In-treatment cooling during thermal modification of wood in soy oil medium: Soy oil uptake, wettability, water uptake and swelling properties. Eur. J. Wood Prod., 67(4):465-470.

Bak M., Németh R., 2012a. Changes in swelling properties and moisture uptake rate of oil-heat-treated poplar (Populus euramericana CV. Pannónia) wood. BioResources, 7, 51285137.

Bak, M., Nemeth, R., 2012b. Modification of wood by oil heat treatment. International Scientific Conference on Sustainable Development \& Ecological Footprint, March 26-27, Sopron, Hungary.

Bazyar, B., Parsapajouh, D., Khademieslam, H., 2010. An Investigation on Some Physical Properties of Oil Heat Treated Poplar Wood. Paper Prepared for the 41st Annual Meeting, Biarritz, France.

Bazyar, B., 2012. Decay resistance and physical properties of oil heat-treated aspen wood. Bioresources, 7: 696-705.

Bourgois, J., Guyonnet, R., 1988. Characterization and analysis of terrified wood. Wood science and Technology, 22(2): 143-155.

Dubey, M.K., Pang, S., Walker J., 2012. Oil uptake by wood during heat-treatment and post-treatment cooling, and effects on wood dimensional stability. European Journal of Wood and Wood Products, 70(1-3): 183-190.

Gündüz, G., Aydemir, D., Karakas, G., 2009. The effects of thermal treatment on the mechanical properties of wild pear (Pyrus elaeagnifolia Pall.) wood and changes in physical properties. Materials and Design, 30: 4391-4395.
Ghalehno, D.M., 2011. Changes in the physical and mechanical properties of Iranian Hornbeam wood (Carpinus betulus) with heat treatment. European Journal of Scientific Research, 51(4):490-498.

Hill, C.A.S., 2006. Wood modification: Chemical, thermal and other processes. John Wiley \& Sons, Chichester. UK.

Kamperidou, V., Barboutis, I., Vasileiou, V., 2013. Response of colour and hygroscopic properties of Scots pine wood to thermal treatment. Journal of forestry research, 24(3): 571-575.

Koski, A., 2008. Applicability of crude tall oil for wood protection. PhD Thesis, Faculty of Technology, Department of Process and Environmental Engineering, University of Oulu, Oulu, Finland, Acta Univ. Oul. C 293.

Metsä-Kortelainen, S., Antikainen, T., Viitaniemi, P., 2006. The water absorption of sapwood and heartwood of Scots pine and Norway spruce heat-treated at 170 C, 190 C, $210 \mathrm{C}$ and $230 \mathrm{C}$. Holz als Roh-und Werkstoff, 64(3): 192-197.

Özan, Z.E., Onat, S.M., Aydemİr, D., 2017. The effects of thermal treatment on the some properties of Scots pine and Uludağ fir woods. Bartın Orman Fakültesi Dergisi, 19(1): 187-193.

Panov, D., Terziev, N., Daniel, G., 2010. Using Plant Oils as Hydrophobic Substances for Wood Protection, 41. IRG Annual Meeting, May, Biarritz, France, IRG-WP.

Rapp, A.O., Sailer M., 2000. Heat treatment of wood in Germany - State of the art. In Proceedings of the Seminar on Production of Heat Treated Wood in Europe, Helsinki, 20 November, Tekes Lahontorjuntayhdistys ry Kestopuu.

Salim, R., Ashaari, Z., Samsi, H.W., Wahab, R., Alamjuri, R.H., 2010. Effect of oil heat treatment on physical properties of semantan bamboo (Gigantochloa scortechinii Gamble). Modern Applied Science, 4(2): 107.

Ulvcrona, T., 2006. Impregnation of Norway spruce (Picea Abies L. Karst.) wood with hydrophobic oil. Ph.D Thesis, Swedish University of Agricultural Sciences, Umeå, Sweden. 10-30550.

TS 2472, 2005. Odunda, fiziksel ve mekaniksel deneyler için birim hacim ağırlığı tayini, TSE, Ankara.

Unsal, O., Ayrilmis, N., 2005. Variations in compression strength and surface roughness of heat-treated Turkish river red gum (Eucalyptus camaldulensis) wood. Journal of Wood Science, 51(4): 405-409.

Wang, J., Cooper, P., 2005. Effect of oil type, temperature and time on moisture properties of hot oil-treated wood. Holz RohWerkst, 63:417-422. 